F. med. Genet. (1965). 2, 161.

\title{
Incidence and Family Aggregation of Major Congenital Malformations of Central Nervous System
}

\author{
ELSPETH M. WILLIAMSON* \\ From the Southampton Group of Hospitals
}

Studies on the incidence of the major congenital malformations of the central nervous system have shown great regional variation (Penrose, 1957). Family studies all indicate a family aggregation of this group of abnormalities (Hindse-Nielsen, 1938; Record and McKeown, I950a, b; Polman, I95I; Milham, 1962), but in none of these studies has a simple genetic pattern appeared, and there are indications that environmental factors such as season of birth and social class are important. This paper reports relevant data on a series of patients from the Southampton area.

\section{Sources for Estimation of Incidence among Births in Borough of Southampton}

To establish the incidence of anencephalus, spina bifida cystica, and hydrocephalus among births in the Borough of Southampton, birth records within the Borough were obtained for the years 1958-1962, and hospital records, in-patient and out-patient, were searched for affected babies born in the Borough. Owing to hospital re-planning programmes, the records for I959 are incomplete, and this year is not included.

Received December 17, 1964.

*Present address: Chirk Lodge, Romsey, Hants.

\section{Results of Incidence Survey}

The numbers of affected babies and the incidence per thousand births for the four years included are shown in Table I. Patients with hydrocephalus in association with spina bifida are classed as spina bifida.

The source of information for the 90 affected babies used in the incidence survey was as follows: 29 cases of anencephalus, 25 cases of spina bifida, and Io cases of hydrocephalus from the Maternity Unit of Southampton General Hospital; I2 cases of spina bifida and 3 cases of hydrocephalus from Southampton Children's Hospital, and a further Io cases of spina bifida from both these hospitals (doubly ascertained) - I other case of spina bifida was reported from a maternity home.

The over-all incidence of anencephalus was $2 \cdot 0$, of spina bifida $3 \cdot 2$, and of hydrocephalus $0 \cdot 9$, per thousand total births.

\section{Material for Family Study}

The notes of patients in the incidence survey were examined, and only those with a full description of the abnormality were accepted as index patients for the family study. In cases of hydrocephalus, where no note was made of the absence of spina bifida, the patient was not included in the family study. 70 index patients were ascertained in this way.

Further index patients were ascertained by including patients born in 1959 and thus not included in the

TABLE I

INCIDENCE OF MAJOR CONGENITAL MALFORMATIONS OF CENTRAL NERVOUS SYSTEM IN SOUTHAMPTON

\begin{tabular}{|c|c|c|c|c|c|c|c|c|}
\hline \multirow{2}{*}{ Year } & \multirow{2}{*}{ Total births } & \multicolumn{2}{|c|}{ Anencephalus } & \multicolumn{2}{|c|}{ Spina Bifida } & \multicolumn{2}{|c|}{ Hydrocephalus } & \multirow{2}{*}{$\begin{array}{l}\text { Total Abnormal } \\
\text { per Thousand }\end{array}$} \\
\hline & & No. & Per Thousand & No. & Per Thousand & No. & Per Thousand & \\
\hline $\begin{array}{l}1958 \\
1960 \\
1961 \\
1962 \\
\end{array}$ & $\begin{array}{l}3,699 \\
3,540 \\
3,7 \text { I I } \\
3,957\end{array}$ & $\begin{array}{r}6 \\
6 \\
10 \\
7\end{array}$ & $\begin{array}{l}1 \cdot 62 \\
1 \cdot 69 \\
2 \cdot 69 \\
1 \cdot 77\end{array}$ & $\begin{array}{r}9 \\
11 \\
13 \\
15\end{array}$ & $\begin{array}{l}2.43 \\
3.11 \\
3.50 \\
3.79\end{array}$ & $\begin{array}{l}5 \\
1 \\
4 \\
3 \\
\end{array}$ & $\begin{array}{l}1 \cdot 35 \\
0.28 \\
1 \cdot 08 \\
0.76 \\
\end{array}$ & $\begin{array}{l}5 \cdot 41 \\
5 \cdot 08 \\
7 \cdot 27 \\
6 \cdot 32 \\
\end{array}$ \\
\hline $\begin{array}{c}\text { Total } \\
\text { 1958-62 }\end{array}$ & 14,907 & 29 & I.95 & 48 & 3.22 & 13 & 0.87 & $6 \cdot 04$ \\
\hline
\end{tabular}


incidence survey. Records of Southampton General Hospital and Southampton Children's Hospital were also searched for notes of affected children born from January 1956 to December 1957. A further 53 index cases were ascertained.

Of these 123 index patients, 22 were not included in the survey: 5 were illegitimate, ro families were untraced, and 7 parents did not wish to co-operate.

The source of information for the remaining ror index patients was as follows : 27 cases of anencephalus, r 4 cases of spina bifida, and 6 cases of hydrocephalus from the Maternity Unit, Southampton General Hospital; 25 cases of spina bifida and 5 cases of hydrocephalus from Southampton Children's Hospital; 20 cases of spina bifida and 4 cases of hydrocephalus were doubly ascertained from the two sources.

The roo families of the IOI index patients were visited at home and a full family and social history elicited. The family study covered sibs, parents, aunts, uncles, and first cousins. No relative was classed as affected unless there was confirmatory evidence from hospital records, general practitioners, or death certificates. The index patients were classified as follows.

Anencephalus-with or without spina bifida: 7 males and 20 females (sex ratio $0 \cdot 35$ ).

Spina bifida-with or without hydrocephalus: 23 males and 36 females (sex ratio 0.64).

Hydrocephalus-without spina bifida, hydrocephalus being apparent in the perinatal period: Io males and 5 females (sex ratio $2 \cdot 0$ ).

\section{Results of the Family Study}

(a) Maternal Age and Birth Order. Th distribution of the index patient by maternal age: and birth order, excluding the stillbirths, was compared with the Registrar General's figures for England and Wales, matching each patient with the distribution of all births in the corresponding year

The mean maternal age for anencephalic birth was $28 \cdot 3$ years; for spina bifida births 25.5 years $\frac{\rho}{3}$ and for hydrocephalic births, 3I.0 years. The corresponding figures for the general populatio $\vec{B}$ were $27 \cdot 6,27 \cdot 7$, and $27 \cdot 7$ years, respectively: The results showed no statistically significan association between maternal age and the develop ment of central nervous system abnormalityo though a high mean maternal age for hydrocephalicu births was noted.

The parity comparisons show an increase i $\vec{\Phi}$ primiparous births of affected children over the number expected from comparison with the generaP population. This is significant at the $1 \%$ leve for the spina bifida and anencephalic patient\$ combined. These figures are shown in Table II

This might, in part, be due to the ascertainmen of cases born in hospital being more complete than of those born elsewhere. All 27 anencephalie index cases were born in hospital, it being the polscp to admit mothers when a diagnosis of anencephaly

TABLE II

BIRTH ORDER OF INDEX PATIENT COMPARED WITH ALL BIRTHS IN SAME YEAR IN ENGLAND AND WALES

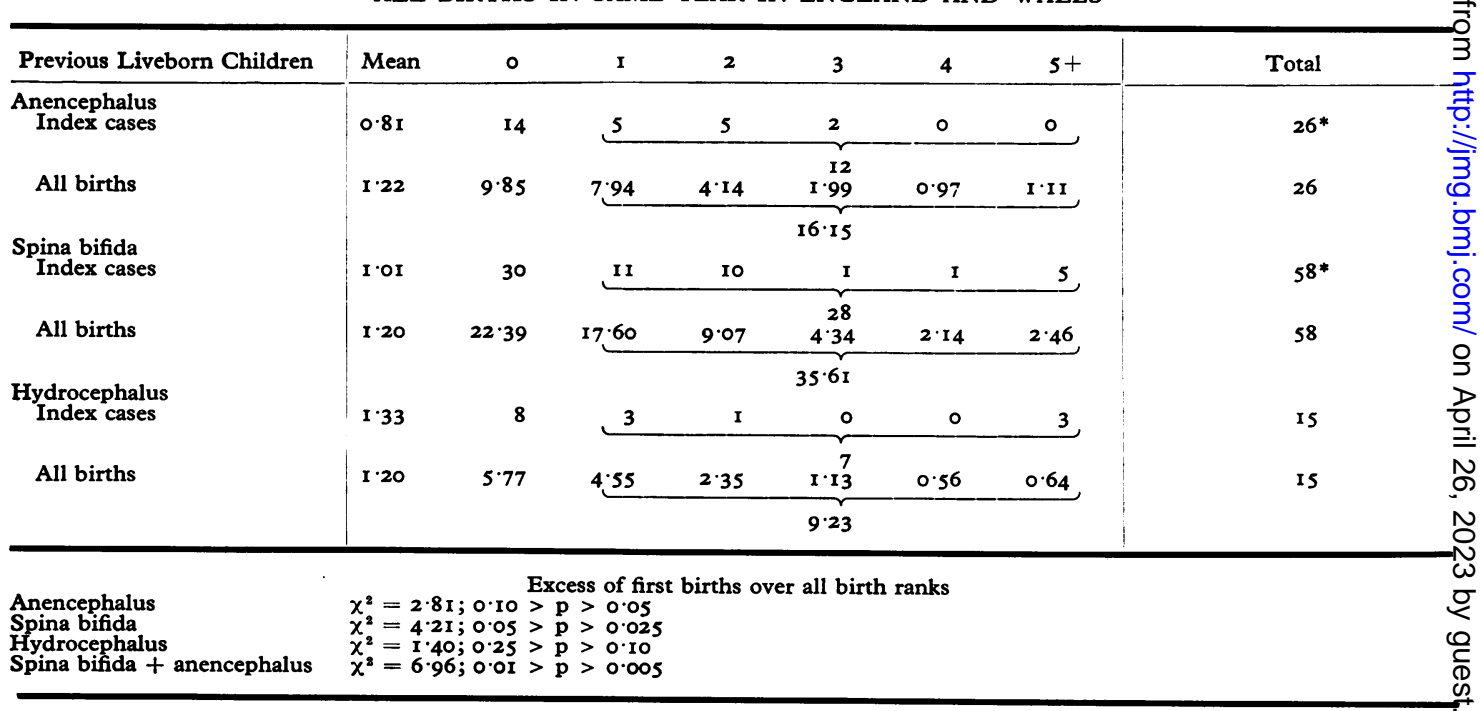

* Excluding one mother who had children by a previous marriage. 
TABLE III

SOCIAL CLASS OF INDEX PATIENT ESTIMATED FROM THE FATHER'S OCCUPATION

\begin{tabular}{|c|c|c|c|c|c|c|}
\hline & \multicolumn{5}{|c|}{ Social Class } & \multirow{2}{*}{ Total } \\
\hline & I & II & III & IV & $\mathbf{V}$ & \\
\hline \multirow[t]{2}{*}{$\begin{array}{l}\text { *Anencephalus } \\
\text { Spina bifida }\end{array}$} & I & I & $\begin{array}{l}16 \\
37 \\
\end{array}$ & $\begin{array}{r}6 \\
14\end{array}$ & $\begin{array}{l}\mathbf{I} \\
4\end{array}$ & $\begin{array}{l}25 \\
59\end{array}$ \\
\hline & 3 & 3 & 53 & 20 & 5 & 84 \\
\hline \multirow[t]{2}{*}{ Southampton general population } & $2 \cdot 44$ & 6 & $46 \cdot 60$ & $9 \cdot 38$ & 13.03 & 84 \\
\hline & \multicolumn{5}{|c|}{ 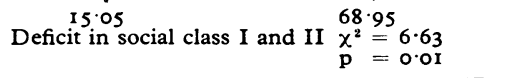 } & \\
\hline $\begin{array}{l}\text { Hydrocephalus } \\
\text { Southampton general population }\end{array}$ & $\overline{0.44}$ & $2 \cdot 25$ & $8 \cdot 30$ & $\begin{array}{r}3 \\
1 \cdot 67\end{array}$ & $2 \cdot 34$ & $\begin{array}{l}\text { is } \\
\text { is }\end{array}$ \\
\hline
\end{tabular}

* Omitting 2 index patients with fathers in the armed services.

is made antenatally. Of these, 13 were primiparous births (one other is classed as firstborn when a previous stillbirth is excluded). Of the spina bifida index cases used in the birth order analysis, 33 were ascertained from Southampton General Hospital, and of these 17 were primiparous and 16 were multiparous births; 2 of the latter are classed as firstborn when previous stillbirths are excluded. The remaining 25 index cases ascertained from the Children's Hospital contained I I primiparous and 14 multiparous births. During the years under review, $53 \%$ of deliveries in Southampton General Hospital were primiparous, so among those index patients born in hospital there is no excess of firstborn over that in all hospital births.

There was no significant trend in parity for hydrocephalic births.

Social Class. The social class of each index family was determined by the father's employment and tabulated according to the Registrar General's classification of occupations in 1960. These figures were compared with the distribution for the general population of Southampton, and the results are shown in Table III.

The figures show a deficit of all 3 abnormalities in social classes I and II. This is significant at the $1 \cdot 5 \%$ level in the spina bifida and anencephalic series. The figures for hydrocephalus show a similar trend but are not significant.

Details of the father's occupation were taken from the mother, but where the mother was of poor intelligence, her description of his employment was not always sufficient for accurate distinction between social classes IV and V; this may account, in part, for the imbalance between these two groups, and they are best combined for a comparison of observed and expected cases.
Seasonal Variation. The date of birth of the index patients and the months of conception (estimated from the recorded date of the last menstrual period) were tabulated. Results are shown in Table IV. The figures give no strong indication of seasonal effect on the incidence of these malformations, with the possible exception of an excess of children with anencephalus conceived in the second quarter, April to June, and born in the first quarter, January to March. Spina bifida births show no similar seasonal incidence and there are too few hydrocephalic births to show seasonal variation.

Maternal Health During Pregnancy. Most mothers were completely healthy during pregnancy. In 9 cases $(8.9 \%)$ there was a history of vaginal bleeding during early pregnancy: in only one was hospital admission necessary; in the other cases neither specific treatment nor bed-rest was considered necessary. There does not seem to be any increase of true threatened abortion over the normal expectation of $2.4 \%$ (Turnbull and Walker, I956). Only one mother admitted to attempted abortion. There was one case each of pneumonia, erythema nodosum, rubella, and jaundice during the first trimester, and five mothers gave a history of influenza. One mother suffered from muscular dystropy, one had a severe electric shock, and one was involved in a road accident but suffered no major injury.

There was no evidence that any particular illness in early pregnancy was associated with the birth of a child with a central nervous system malformation.

Drugs During Pregnancy. Six mothers obtained 'tablets' from their doctors for sickness and 
TABLE IV

SEASON OF BIRTH AND CONCEPTION OF IOI INDEX PATIENTS

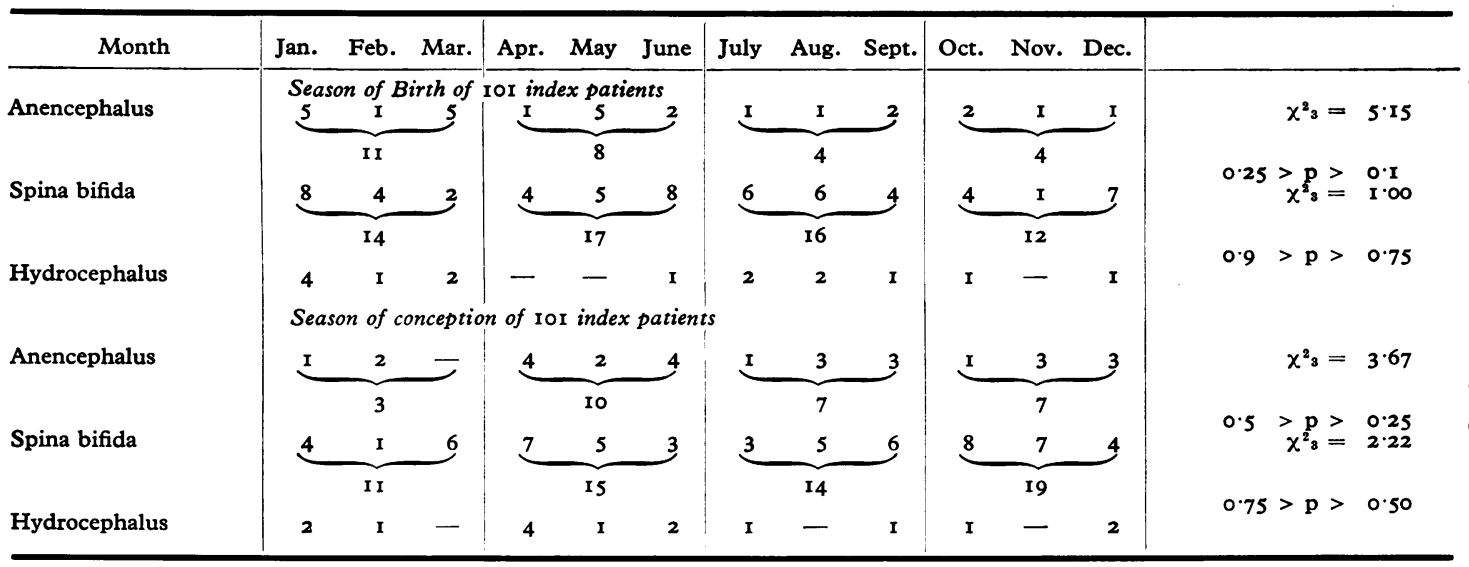

two took Preludin. The only mother to take a drug throughout pregnancy was a thyrotoxic patient on thiouracil. She had one anencephalic baby, and during a subsequent pregnancy again took thiouracil throughout and produced a second anencephalic infant. This is of interest since methyl thiouracil given to pregnant rabbits will produce abnormalities in foetal brain and skull (Yankova, 196I).

Sex Ratio. The sex ratio is shown in the classification of index patients. The results show the usual female preponderance in anencephaly and spina bifida, the effect being most marked in the more severe abnormality, anencephalus. In contrast, with hydrocephalus, there is an excess of males.
Family Study. The families of the index $\stackrel{5}{\longrightarrow}$ patients are summarized in the Appendix.

Foetal Loss Among Sibs. Stillbirths and abortions occurring within the index families (excluding the pregnancy resulting in the index patient) are shown in Table $\mathrm{V}$ and the stillbirth rate is compared with that of all births in Southampg ton Borough during the years 1958-1962.

The stillbirth rate in the index families $(5.7 \%$ is more than double that found in the generat population of Southampton, but when stillbirths due to central nervous system malformations are excluded the rate falls to 2.6 per Ioo births, not significantly above the general rate of stillbirths, which is about $2 \%$. The rate is higher for anen-

TABLE V

TOTAL PREGNANCIES WITHIN INDEX FAMILIES; STILLBIRTH RATES COMPARED WITH THAT IN SOUTHAMPTON BOROUGH

\begin{tabular}{|c|c|c|c|c|c|c|c|c|c|c|}
\hline & & & Live Births & & & Stillbirths & & & & Stillbirths \\
\hline & Abortions & $\begin{array}{c}\text { With } \\
\text { Central } \\
\text { Nervous } \\
\text { System } \\
\begin{array}{c}\text { Malfor- } \\
\text { mation }\end{array}\end{array}$ & $\begin{array}{l}\text { With } \\
\text { Other } \\
\text { Con- } \\
\text { genital } \\
\text { Malfor- } \\
\text { mation }\end{array}$ & $\begin{array}{l}\text { Normally } \\
\text { Formed }\end{array}$ & $\begin{array}{l}\text { With } \\
\text { Central } \\
\text { Nervous } \\
\text { System } \\
\begin{array}{c}\text { Malfor- } \\
\text { mation }\end{array}\end{array}$ & $\begin{array}{l}\text { With } \\
\text { Other } \\
\text { Con- } \\
\text { genital } \\
\text { Malfor- } \\
\text { mation }\end{array}$ & $\begin{array}{l}\text { Normally } \\
\text { Formed }\end{array}$ & Total Births & $\begin{array}{c}\text { Stillbirths } \\
\text { per } \\
\text { 100 Births }\end{array}$ & $\begin{array}{c}\text { With } \\
\text { Central } \\
\text { Nervous } \\
\text { System } \\
\text { Malfor- } \\
\text { mation } \\
\text { per } \\
\text { 100 Births }\end{array}$ \\
\hline $\begin{array}{l}\text { Anencephalus } \\
\text { Spina bifida } \\
\text { Hydrocephalus }\end{array}$ & $\begin{array}{r}8 \\
25 \\
9\end{array}$ & $\begin{array}{l}0 \\
4 \\
0\end{array}$ & $\begin{array}{l}0 \\
4 \\
1\end{array}$ & $\begin{array}{r}37 \\
105 \\
29\end{array}$ & $\begin{array}{l}2 \\
3 \\
1\end{array}$ & $\begin{array}{l}\mathbf{I} \\
0 \\
0\end{array}$ & $\begin{array}{l}\mathbf{1} \\
3 \\
0\end{array}$ & $\begin{array}{r}41 \\
119 \\
31\end{array}$ & $\begin{array}{l}9 \cdot 8 \\
5 \cdot 0 \\
3 \cdot 2 \\
\end{array}$ & $\begin{array}{l}4 \cdot 9 \\
2 \cdot 5 \\
\end{array}$ \\
\hline $\begin{array}{l}\text { All } 3 \\
\text { malformations } \\
\text { All births in } \\
\text { Southampton } \\
\text { Borough } \\
1958-62\end{array}$ & 42 & 4 & $\begin{array}{c}5 \\
14,585\end{array}$ & 171 & $5 \mathbf{I}$ & $\begin{array}{r}\mathbf{I} \\
271\end{array}$ & 4 & $\begin{array}{c}191 \\
14,907\end{array}$ & $\begin{array}{l}5 \cdot 7 \\
2 \cdot 2\end{array}$ & $\begin{array}{l}2 \cdot 6 \\
1 \cdot 8\end{array}$ \\
\hline
\end{tabular}


TABLE VI

INCIDENCE OF CENTRAL NERVOUS SYSTEM ABNORMALITY IN SIBS OF INDEX PATIENTS

\begin{tabular}{|c|c|c|c|c|c|c|c|c|c|c|c|c|c|}
\hline & \multirow[b]{3}{*}{ Index Patient } & \multicolumn{4}{|c|}{ Sibs Before Index Patient } & \multicolumn{4}{|c|}{ Sibs After Index Patient } & \multicolumn{4}{|c|}{ Total } \\
\hline & & \multicolumn{2}{|c|}{ Brothers } & \multicolumn{2}{|c|}{ Sisters } & \multicolumn{2}{|c|}{ Brothers } & \multicolumn{2}{|c|}{ Sisters } & \multicolumn{2}{|c|}{ Brothers } & \multicolumn{2}{|c|}{ Sisters } \\
\hline & & Total & Affected & Total & Affected & Total & Affected & Total & Affected & Total & Affected & Total & Affected \\
\hline \multirow{2}{*}{ Anencephalus } & $\{$ Male & 4 & $\circ$ & 5 & I(A) & $\mathbf{I}$ & o & $\circ$ & 0 & 5 & $\circ$ & 5 & I(A) \\
\hline & Gemale & I0 & $\circ$ & 6 & $\circ$ & 8 & ○ & 7 & $I(A)$ & 18 & $\circ$ & 13 & $\mathrm{I}(\mathrm{A})$ \\
\hline \multirow{2}{*}{ Spina bifida } & Male & 20 & $\circ$ & 16 & $\circ$ & 9 & $\circ$ & 7 & $\mathbf{I}(\mathbf{S})$ & 29 & $\circ$ & 23 & $\mathbf{I}(\mathbf{S})$ \\
\hline & Female & 23 & $\begin{array}{l}3(\mathrm{IA}) \\
(\mathbf{2 S})\end{array}$ & $2 \mathbf{I}$ & $2(S)$ & 14 & ० & 9 & $\mathbf{I}(\mathbf{S})$ & 37 & $\begin{array}{c}3(\mathbf{I A}) \\
(\mathbf{2 S})\end{array}$ & 30 & $3(S)$ \\
\hline \multirow{2}{*}{ Hydrocephalus } & $\{$ Male & 10 & $\mathrm{I}(\mathrm{H})$ & 8 & 0 & I & 0 & 2 & 0 & II & $\mathbf{I}(\mathbf{H})$ & 10 & 0 \\
\hline & (Female & 3 & $\circ$ & 5 & 0 & 2 & 0 & 0 & $\circ$ & 5 & 0 & 5 & $\circ$ \\
\hline
\end{tabular}

Form of abnormality in brackets: $A$, anencephalus; $S$, spina bifida; $H$, hydrocephalus

cephalus alone, but this is not significant with such small numbers.

The 5 stillbirths not associated with central nervous system abnormality were due to multiple congenital abnormalities (I), prematurity (2), strangulation by the cord (I), and cause unknown (I).

There were 42 abortions in a total of 233 pregnancies (18\%). Considering the malformations individually, abortion rates are found to be $16 \cdot 3 \%$ among anencephalic families, $17 \cdot 3 \%$ among spina bifida families, and $22.5 \%$ among hydrocephalic families. This shows no significant increase over the normal expectation of about $15 \%$ (Warburton and Fraser, 1964).

Major Malformations Other Than Those of Central Nervous System among Sibs of Index Patients. The I9I sibs included children with the following major malformations other than those of the central nervous system: one stillborn child with abnormally formed lower jaw, tumour of the palate, and talipes; one child deaf with hemiplegia and one child with paraplegia, both in one family; one child with facial asymmetry and one microphthalmic blind eye; one child with harelip and cleft palate; one child with congenital heart disease. This is no more than the random expectation of congenital abnormalities.

Central Nervous System Malformations Among Sibs. The incidence of central nervous system malformation in the brothers and sisters of index patients is summarized in Table VI, distinguishing those born before and those born after the index patient.
Two families contained 2 anencephalic infants, one family contained 3 infants with spina bifida, 3 families contained 2 infants with spina bifida (in one of these both infants were index patients), and in one family there was one child with spina bifida and a sib with anencephalus.

There is no significant difference in the proportion of sibs affected between those born before and those born after the index patient, so these may reasonably be combined. There were $4 \mathrm{I}$ sibs of index patients with anencephalus of whom 2 were similarly affected, II9 sibs of index patients with spina bifida of whom 6 had spina bifida and I had anencephalus.

Combining these 2 sets of figures, 9 sibs in 160 were affected, an incidence of $5.6 \%$ or $I$ in 18 . The abnormality was more often of the same type in index patient and affected sib.

In the hydrocephalic series there was one affected child in 31 sibs (Index patient 33). This was a male stillbirth occurring in hospital and recorded as hydrocephalic without spina bifida. No necropsy was performed. The index patient in this family was a male with hydrocephalus who survived 2 months, but again there was no necropsy. A son of the mother's maternal aunt was stillborn and was thought to have hydrocephalus, but confirmation was not available. In this family the recurrence of the abnormality is suggestive of sexlinked recessive inheritance (Edwards, 196I). The pedigree is shown in Fig. I.

A second family also suggests this type of inheritance (Index patient 4I). Two brothers of the mother of the male index patient were stillborn, one was a proven hydrocephalic and the other was possibly affected. The pedigree is shown in Fig. 2. 


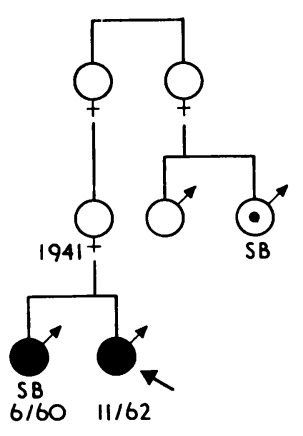

Fig. I. Family tree of index patient No. 33.

Central Nervous System Malformation in Other Relatives. The incidence of central nervous system malformation in uncles, aunts, and first cousins is shown in Table VII.

This shows, among relatives of index patients with spina bifida and anencephalus, that 3 maternal aunts of index patients had spina bifida, and 9 out of 58I first cousins had either anencephalus or spina bifida. Confirmation of the diagnosis was available in all but one case where hydrocephalus was mentioned, but there was no note as to presence or absence of spina bifida. Of the affected first cousins, 8 were children of the index patient's mother's sister. The affected relative was commonly suffering from the same malformation as that of the index patient.

There were no known cases of hydrocephalus among the aunts or first cousins of the hydrocephalic series. The 2 affected uncles occurred in one family where sex-linked recessive inheritance has been considered.

Twins. Three sets of twins were included in the family study. One index patient (Case 26) was a female stillborn anencephalic whose twin was a normal live-born female. The placenta was said to be single but no further investigations were made. These twins were, therefore, possibly monozygotic. Another anencephalic index patient $\underset{\hat{\omega}}{\hat{\omega}}$ (Case 27) was a stillborn female whose female stillborn twin was said to be hydrocephalic-notes $\stackrel{9}{\rightarrow}$ do not mention whether there was associated spina 을 bifida. It was recorded that two placentae were present but no other investigations were carried $\infty$ out. It is therefore probable, but by no means $\frac{\mathbb{D}}{0}$ certain, that these twins were dizygotic.

A further twin index patient (Case 28), a male

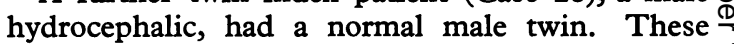
two have been fully blood-grouped and are con- $\vec{\theta}$ cordant for the following groups: $\mathrm{ABO}, \mathrm{Rh}, \mathrm{MN}$, o $\mathrm{S}, \mathrm{Pl}, \mathrm{Lu}^{\mathrm{a}}, \mathrm{K}$, and $\mathrm{Fy}^{\mathrm{a}}$. They are also similar hair colour, eye colour, head shape, finger-n shape, teeth pattern, and many other features and are very probably monozygotic.

\section{Discussion}

Incidence. The incidence of central nervous system malformations in this series from Southampton Borough is best compared with those of the other community surveys listed in the first part of Table VIII. The figures for anencephalus and spina bifida agree with those from Birmingham, and the higher incidence of hydrocephalus in the latter series is presumably due to the inclusion of $O$ cases with postnatal onset. The Northampton

TABLE VII

NUMBERS OF UNCLES, AUNTS, AND FIRST COUSINS OF INDEX PATIENTS

\begin{tabular}{|c|c|c|c|c|c|c|c|c|}
\hline & $\begin{array}{l}\text { Father's } \\
\text { Brothers }\end{array}$ & $\begin{array}{l}\text { Father's } \\
\text { Brothers' } \\
\text { Children }\end{array}$ & $\begin{array}{l}\text { Father's } \\
\text { Sisters }\end{array}$ & $\begin{array}{l}\text { Father's } \\
\text { Sisters' } \\
\text { Children }\end{array}$ & $\begin{array}{l}\text { Mother's } \\
\text { Brothers }\end{array}$ & $\begin{array}{l}\text { Mother's } \\
\text { Brothers' } \\
\text { Children }\end{array}$ & $\begin{array}{l}\text { Mother's } \\
\text { Sisters }\end{array}$ & $\begin{array}{l}\text { Mother's } \\
\text { Sisters' } \\
\text { Children }\end{array}$ \\
\hline Anencephalus & 50 & 32 & 43 & 34 & 47 & 30 & 43 & $60(3 \mathrm{~A})$ \\
\hline Spina bifida & 97 & 64 (IS) & 95 & 98 & 114 & 116 & $107(3 S)$ & $147(2 S)$ \\
\hline Hydrocephalus & $3 \mathbf{I}$ & 18 & 29 & 12 & $27(2 \mathrm{H})$ & 36 & 22 & 25 \\
\hline
\end{tabular}


TABLE VIII

INCIDENCE OF CONGENITAL CENTRAL NERVOUS SYSTEM MALFORMATIONS

\begin{tabular}{|c|c|c|c|c|c|c|c|}
\hline & \multirow{2}{*}{ Region } & \multirow{2}{*}{ Authors } & \multirow{2}{*}{ Dates } & \multicolumn{4}{|c|}{ Incidence per Thousand Births } \\
\hline & & & & Anence & phalus & Spina Bifida & Hydrocephalus \\
\hline \multirow{5}{*}{ Community s.urveys } & Northamptonshire & Pleydell (1960) & $1944-57$ & & $\mathbf{I} \cdot \mathbf{I}$ & $2 \cdot 0$ & 0.6 \\
\hline & Belfast & Stevenson and Warnock (1959) & 1957 & & $4 \cdot 6$ & $2 \cdot 2$ & $1 \cdot 5$ \\
\hline & Charleston S.C. & Alter (1962) & $1946-55\{$ & $\begin{array}{l}\text { Whites } \\
\text { Negroes }\end{array}$ & $\begin{array}{l}1 \cdot 2 \\
0 \cdot 2\end{array}$ & $\begin{array}{l}1 \cdot 5 \\
0.6\end{array}$ & $\begin{array}{l}0.8 \\
I \cdot 1\end{array}$ \\
\hline & Southampton & Present survey & & & I 9 & $3 \cdot 2$ & 0.9 \\
\hline & $\begin{array}{l}\text { Birmingham } \\
\text { Liverpool }\end{array}$ & $\begin{array}{l}\text { Record and McKeown (1960) } \\
\text { Smithells et al. (1964) }\end{array}$ & $\begin{array}{l}1950-52 \\
1960-62\end{array}$ & & $\begin{array}{l}2 \cdot 0 \\
3 \cdot 3 \\
\end{array}$ & $3 \cdot 0$ & $2 \cdot 6$ \\
\hline \multirow[t]{2}{*}{ Stillbirth records } & Edinburgh & Edwards (1958) & $1950-56$ & & $2 \cdot 7$ & I 4 & $\mathbf{I} \cdot \mathbf{I}$ \\
\hline & Glasgow & Edwards (1958) & $1950-56$ & & $3 \cdot 0$ & $\mathrm{I} \cdot \mathbf{8}$ & $I \cdot 4$ \\
\hline \multirow[t]{2}{*}{$\begin{array}{l}\text { Stillbirth records } \\
\text { and deaths in } \\
\text { first year }\end{array}$} & Birmingham & Record and McKeown (I949) & $1940-47$ & & $2 \cdot 3$ & $2 \cdot 5$ & $1 \cdot 0$ \\
\hline & Dublin & Coffey and Jessop (1959) & $1953-55$ & & $5 \cdot 9$ & - & - \\
\hline \multirow[t]{2}{*}{ Hospital surveys } & Rhode Island & Ingalls et al. (1954) & $1936-52$ & & I $\cdot 9$ & $2 \cdot 5$ & 0.9 \\
\hline & Melbourne & Collmann and Stoller (1962) & $1942-57$ & & 0.7 & 0.6 & 0.6 \\
\hline
\end{tabular}

figures from a predominantly rural area are substantially lower. The Belfast series shows the high incidence of anencephalus characteristic of Ireland, and the high incidence in Liverpool (Smithells, Chinn, and Franklin, 1964) is possibly due to Irish immigration.

The series based on stillbirths will naturally underestimate the incidence of spina bifida and hydrocephalus, while the hospital series will be expected to show a higher incidence than community series as a result of emergency admissions for hydramnios and obstructed labour. The American 'White' series is compatible with the English series. It is interesting, however, that the hospital series from Melbourne shows a strikingly lower incidence, and it is perhaps doubtful whether this can be entirely attributed to the recent immigration to Australia from central and southern Europe. Further hospital series for anencephalus are listed by Penrose (1957).

The ratio of the three abnormalities in Southampton is approximately $53 \%$ spina bifida, $32 \%$ anencephalus, and $15 \%$ hydrocephalus. The proportion of spina bifida cases in this series, which includes survivors, is naturally higher than in surveys ascertained from stillbirths and neonatal deaths. The care taken to separate as far as possible cases of hydrocephalus, which were not associated with spina bifida, from those with both abnormalities, will also have raised the proportion of spina bifida patients; but even in this series some stillborn cases of hydrocephalus may have had unrecorded spina bifida.

Environmental Factors. The results of the present survey agree with previous surveys that certain probably environmental factors are involved in the aetiology of congenital malformations of the central nervous system. These environmental factors appear to be similar for anencephalus and spina bifida, but differ from those involved for hydrocephalus.

The high mean maternal age for hydrocephalus in the series and a normal mean maternal age for anencephalus and spina bifida conforms with the findings of Record and McKeown (1949), Edwards (1958), and Collmann and Stoller (1962). There is some doubt as to the significance of the finding in the present series of an excess of firstborn children in all three groups, particularly spina bifida and anencephalus, because of a possible bias towards more complete ascertainment among hospital births. However, Record and McKeown (1949), Ingalls, Pugh, and MacMahon (1954), Edwards (1958), and Collmann and Stoller (1962) all found an association between first births and central nervous system abnormality. The association of anencephalus (but not hydrocephalus) with high parity, as well as primiparity, found by all the authors mentioned above is not apparent in this series.

The present finding that the incidence of anen- 
cephalus and spina bifida is significantly lower among social classes I and II than among the other social classes confirms Edwards's demonstration of a social class effect for anencephalus in Scottish stillbirth data (1958). In Dublin, Coffey and Jessop (1957) found a low plasma protein and haemoglobin level among mothers of anencephalics, indicating low economic level. In Birmingham, however, Record and McKeown (I949) found no association between socio-economic class (assessed from locality and rent of house) and the occurrence of abnormality.

Seasonal variation in the incidence of anencephalus has been described by Record and McKeown (1949) and Edwards (1958) with a peak in the half-year October-March. Guthkelch (1962) described a similar peak for spina bifida. No seasonal variation for hydrocephalus has been reported. The present series shows a small and non-significant increase in anencephalic births during the first quarter of the year, i.e. January-March. A recent survey in Liverpool (Smithells et al., 1964) and surveys outside the United Kingdom have failed to show this seasonal variation (MacMahon, Pugh, and Ingalls, 1953; Smilkstein, 1962).

A high mean temperature at the time of conception has been suggested as a cause of the seasonal variation, but this seems improbable as the incidence of anencephaly is very low in hot countries (Penrose, 1957). A possibility of seasonal dietary variation should be considered though there is no evidence for this at present.

Maternal health during pregnancy with the index patient shows no evidence of infectious illness during early pregnancy in this survey or in other series (Record and McKeown, 1949).

Genetic Factors. The sex ratio in the present series shows the usual large preponderance of affected females with anencephalus and a less marked preponderance with spina bifida. In hydrocephalics the sex ratio is reversed.

The twins in the present study add nothing new to those already reported (Dumoulin and Gordon, 1959; Litt and Strauss, 1935; Fry, 1943; Stroink, 1937; Record and McKeown, I95I) and give no indication whether genetic factors are involved in the aetiology of central nervous system malformations. It is certain that the majority of monozygotic twin pairs are discordant for anencephaly and spina bifida cystica, and there is no clear indication yet that concordance is higher for monozygotic than for dizygotic pairs.

In the family study there is evidence of familial concentration of these malformations. There were
I9I other pregnancies of the mothers of the index patients, which lasted more than 28 weeks; of these I7I resulted in normal live babies, 4 in normally-formed stillbirths, 10 in babies also affected with central nervous system malformations, and 6 in babies born with other serious congenital malformations, though only one was sufficiently severe to cause stillbirth. This confirms the findings of Record and McKeown (1950a, b), MacMahon et al. (1953), and other workers that there is an increased risk to sibs of central nervous system malformations, but no increased risk of other congenital abnormality. In this series there was no increase of stillbirths (other than those due to central nervous system malformation) over the expected rate.

Hydrocephalus appears as a distinct entity from anencephalus and spina bifida and is considered separately in the family study. There was one recurrence of hydrocephalus within a fraternity and two maternal uncles were affected with hydrocephalus, but no relatives were known with spina bifida or anencephalus. Recurrence of hydrocephalus within a fraternity where only males are affected has been described by Bickers and Adams (1949), Edwards, Norman, and Roberts (I96r), Zimmer (1952), Needleman and Root (1963), Gellman (I959), and Warren, Lu, and Ziering (1963). The patients in these families have a specific abnormality-stenosis of the aqueduct of Sylvius-transmitted as a sex-linked recessive characteristic. The family in the present series with 2 affected males probably belongs to this group, but necropsy has not been performed. However, recurrence of hydrocephalus has also been reported in a fraternity of mixed sexes and of females only (Mehne, I960; Kovats, 1940), so a sex-linked recessive gene cannot be responsible for all familial cases.

Previous family studies of anencephalus and spina bifida show a recurrence in sibs not significantly different from the Southampton finding of $I$ in $I 8$ sibs affected. The methods of ascertainment in other surveys are not all similar, but the most comparable figures are those of Record and McKeown (1950a, b) who found 12 of 407 sibs to be affected. Milham (I962) from records only found to of 308 sibs affected, and MacMahon et al. (1953) 17 of 285 sibs. Two earlier surveys, Polman (195I) in Holland and Hindse-Nielsen (1938) in Denmark, found 24 of 357 and 28 of 548 sibs affected, respectively.

Relatives, other than sibs, also affected with anencephalus or spina bifida are more numerous than would be expected in the general population; 
this is particularly so for maternal relatives. It is a striking result that of 228 paternal first cousins only $I$ is affected, but of 353 maternal first cousins 8 are affected and all those affected are children of the mother's sisters. Even allowing for the fact that the mother (from whom the history was in most instances taken) has a more thorough knowledge of her own family than of her husband's, maternal relatives seem to be more commonly affected than paternal relatives. This was also found by Hindse-Nielsen (1938) and Record and McKeown (I950a, b).

A proportion of $\mathrm{I}$ sib in $\mathrm{I} 8$ being affected does not suggest any simple type of genetic determination of spina bifida and anencephalus. Böök and Rayner (1950) suggested that these were recessive conditions with many of the affected zygotes, particularly males, presenting as early abortions. An abortion rate of $18 \%$ for the other pregnancies of mothers of index patients in this series does not differ significantly from Warburton and Fraser's (1964) figure of $15 \%$ in random pregnancies, and though some embryos with central nervous system malformation do abort, the suggestion of recessive inheritance is implausible.

A multifactorial aetiology seems more tenable. The finding in the present series of an increased risk to the children of maternal aunts suggests that some genetic factor acts in the mother in such a way that the uterine environment she provides for the growing foetus predisposes towards development of anencephalus and spina bifida cystica. Environmental factors, and particularly those associated with low socio-economic status, acting on the predisposed foetus increase the risk of occurrence of these malformations.

\section{Summary}

The incidence of the major congenital abnormalities of the central nervous system within Southampton Borough, I958-1962, was estimated at 6.0 per thousand total births, $2 \cdot 0$ anencephalus, $3 \cdot 2$ spina bifida, 0.9 hydrocephalus.

A study of IOI index patients and their families showed similarities between aetiological factors involved for spina bifida and anencephalus, distinct from those involved for hydrocephalus.

The occurrence of spina bifida and anencephalus was associated with a normal mean maternal age, was increased with primiparity, was low in social class I and II, and showed a female preponderance. A recurrence within the fraternity was commonly of the same malformation, but anencephalus did occur in the fraternity of a spina bifida index patient. A risk of $I$ in $I 8$ to sibs was found. Mater- nal relatives were affected at a higher rate than expected, and it is suggested that a familial maternal factor is involved in the aetiology of these $a b-$ normalities.

Three sets of twins included a monozygotic pair with only one affected and two sets of unknown zygosity, one with both affected and one with only one affected.

I am grateful to the obstetricians and paediatricians of Southampton Hospitals for allowing me access to their case records and to the general practitioners for their help and permission to visit their patients.

I am indebted to Dr. Cedric Carter of the Medical Research Council's Clinic Genetics Research Unit at the Institute of Child Health, London, for much help and valuable suggestions.

I am also indebted to the Eugenics Society for providing me with a grant towards the expenses of this survey.

\section{REFERENCES}

Alter, M. (1962). Anencephalus, hydrocephalus and spina bifida. Arch. Neurol. (Chic.), 7, 411 .

Bickers, D. S., and Adams, R. D. (1949). Hereditary stenosis of the aqueduct of Sylvius as a cause of congenital hydrocephalus. Brain, 72, 246.

Böök, J. A., and Rayner, S. (1950). A clinical and genetical study of anencephaly. Amer. F. hum. Genet., 2, 61.

Coffey, V. P., and Jessop, W. J. E. (1957). A study of 137 cases of anencephaly. Brit. F. prev. soc. Med., II, 174.

, and - (1959). Maternal influenza and congenital deformities. A prospective study. Lancet, 2, 935 .

Collmann, R. D., and Stoller, A. (I962). Epidemiology of congenital anomalies of the central nervous system with special reference to patterns in the State of Victoria, Australia. F. ment. defic. Res., 6, 22.

Dumoulin, J. G., and Gordon, M. E. (1959). Anencephaly in twins. F. Obstet. Gynaec. Brit. Emp., 66, 964.

Edwards, J. H. (1958). Congenital malformations of the central nervous system in Scotland. Brit. F. prev. soc. Med., 12, I 15. (1961). The syndrome of sex-linked hydrocephalus. Arch. Dis. Childh., 36, 486.

- Norman, R. M., and Roberts, J. M. (I96I). Sex-linked hydrocephalus. Report of a family with 15 affected members. ibid., 36, 481 .

Fry, A. (1943). Spina bifida in binovular twins. Brit. med. f., I, I3I.

Gellman, V. (1959). Congenital hydrocephalus in monovular twins. Arch. Dis. Childh., 34, 274.

Guthkelch, A. N. (1962). Studies in spina bifida cystica. III. Seasonal variation in the frequency of spina bifida births. Brit. F. prev. soc. Med., 16, 159 .

Hindse-Nielsen, S. (1938). Spina Bifida. Prognose. Erblichkeit. Eine Klinische Stdie. Acta chir. scand., 80, 525.

Ingalls, T. H., Pugh, T. F., and MacMahon, B. (1954). Incidence of anencephalus, spina bifida, and hydrocephalus related to birth rank and maternal age. Brit. F. prev. soc. Med., 8, 17.

Kovats, K. (1940). Ismétlödö veleszületett vízfejüseg. [Recurrent congenital hydrocephalus.] Orv. Hetil., 84, 531 .

Litt, S., and Strauss, H. A. (1935). Monoamniotic twins, one normal, the other anencephalic: multiple true knots in the cords. Amer. f. Obstet. Gynec., 30, 728.

MacMahon, B., Pugh, T. F., and Ingalls, T. H. (1953). Anencephalus, spina bifida, and hydrocephalus. Incidence related to sex, race, and season of birth, and incidence in siblings. Brit. F. prev. soc. Med., 7, 211 .

Mehne, R. G. (1960). Three hydrocephalic newborns-each of a successive pregnancy of a white female. $\mathcal{F}$. Indiana med. Ass., 53, 1472 . 
Milham, S., Jr. (1962). Increased incidence of anencephalus and spina bifida in siblings of affected cases. Science, 138, 593.

Needleman, H. L., and Root, A. W. (1963). Sex-linked hydrocephalus. Report of 2 families, with chromosomal study of 2 cases. Pediatrics, 31, 396.

Penrose, L. S. (1957). Genetics of anencephaly. f. ment. Defic. Res., 1, 4.

Pleydell, M. J. (1960). Anencephaly and other congenital abnormalities: an epidemiologic study in Northamptonshire. Brit. med. F., 1, 309.

Polman, A. (195I). Anencephaly, spina bifida and hydrocephaly. Genetica, 25, 29.

Record, R. G., and McKeown, T. (1949). Congenital malformations of the central nervous system. I-A survey of 930 cases. Brit. F. soc. Med., 3, 183.

$\longrightarrow$, and - (1950a). Congenital malformations of the central nervous system. II-Maternal reproductive history and familial incidence. ibid., 4, 26.

$\longrightarrow$, and - (1950b). Congenital malformations of the central nervous system. III-Risk of malformation in sibs of malformed individuals. ibid., $4,217$.

- , and - (I95I). Congenital malformations of the central nervous system. Data on 69 pairs of twins. Ann. Eugen. (Lond.), $15,285$. $\longrightarrow$, and - (1960). Malformations in a population observed for five years after birth. Ciba Foundation Symposium on Congenital Malformations.

Smilkstein, G. (1962). A ten-year study of anencephaly. Calif. Med., 96, 350.

Smithells, R. W., Chinn, E. R., and Franklin, D. (1964). Anencephaly in Liverpool. Develop. Med. Child. Neurol., 6, 23 I.

Stevenson, A. C., and Warnock, H. A. (1959). Observations on the results of pregnancies in women resident in Belfast. I. Data relating to all pregnancies ending in 1957. Ann. hum. Genet., 23, 382.

Stroink, J. A. (1937). Hydrocephalie bij tweelingen en erfelijkheidsonderzoek. Ned. T. Geneesk., 81, 779.

Turnbull, E. P. N., and Walker, J. (1956). The outcome of pregnancy complicated by threatened abortion. 7. Obstet. Gynaec. Brit. Emp., 63, 553.

Warburton, D., and Fraser, F. C. (1964). Spontaneous abortion risks in man. Amer. J. hum. Genet., 16, I.

Warren, M. C., Lu, A. T., and Ziering, W. H. (1963). Sex-linked hydrocephalus with aqueductal stenosis. F. Pediat., 63, 1 I04.

Yankova, M. F. (1961). The effects of maternal thyroid dysfunction during pregnancy on the development of the foetus and the child. Thesis, Academy of the Medical Sciences of U.S.S.R. Moscow

Zimmer, K. (1952). Utber familiäres Auftreten von Hydrozephalus. Geburtsh. u. Frauenheilk., 12, 447.

\section{APPENDIX}

$M=$ male; $F=$ female; $m=$ miscarriage; s.b. = stillbirth; $*$ = index case; ec. = ectopic pregnancy; $M-F=$ affected sibs; $(A)=$ anencephaly; $(H)=$ hydrocephaly; $(S)=$ spina bifida; $(M)=$ microcephaly .

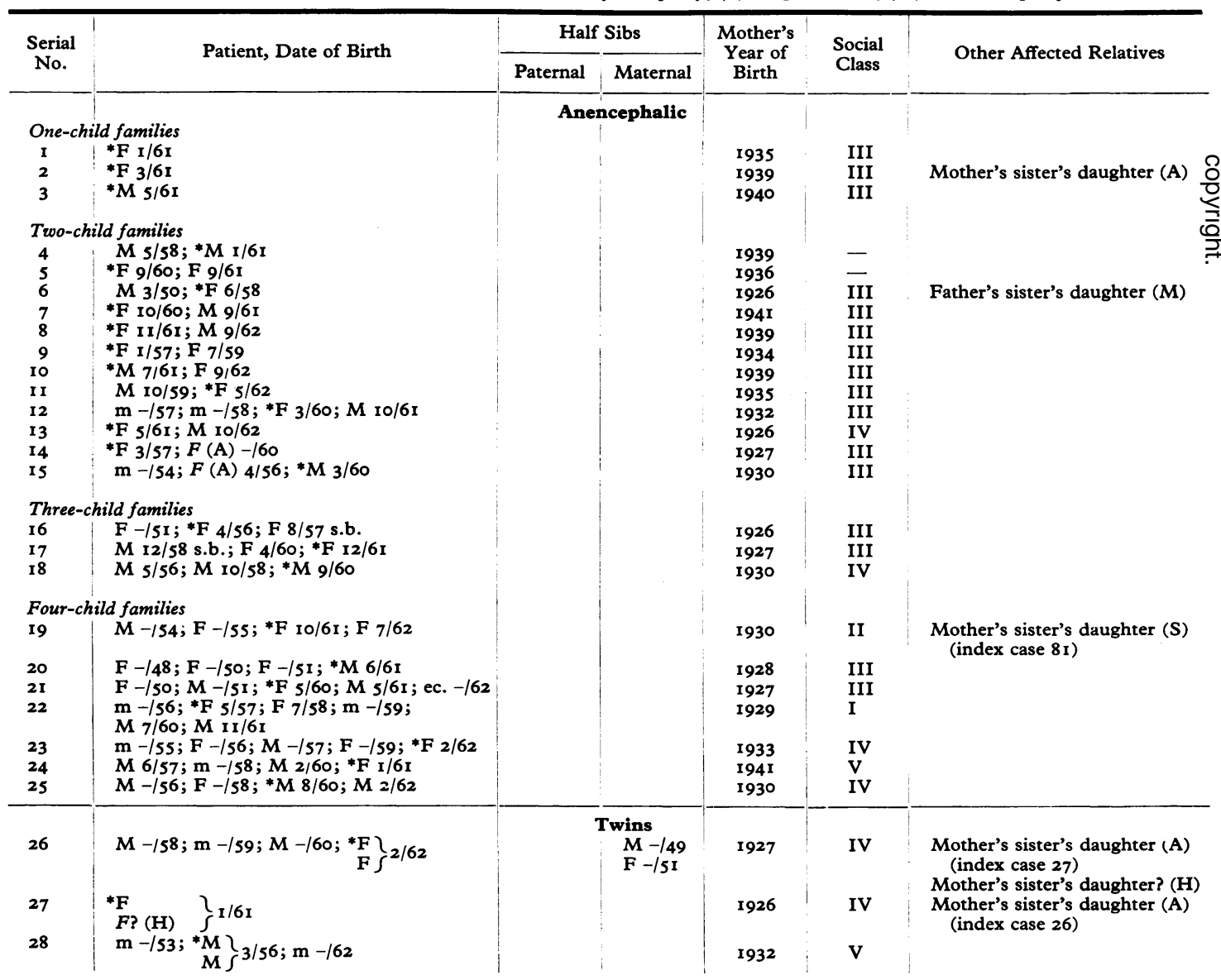




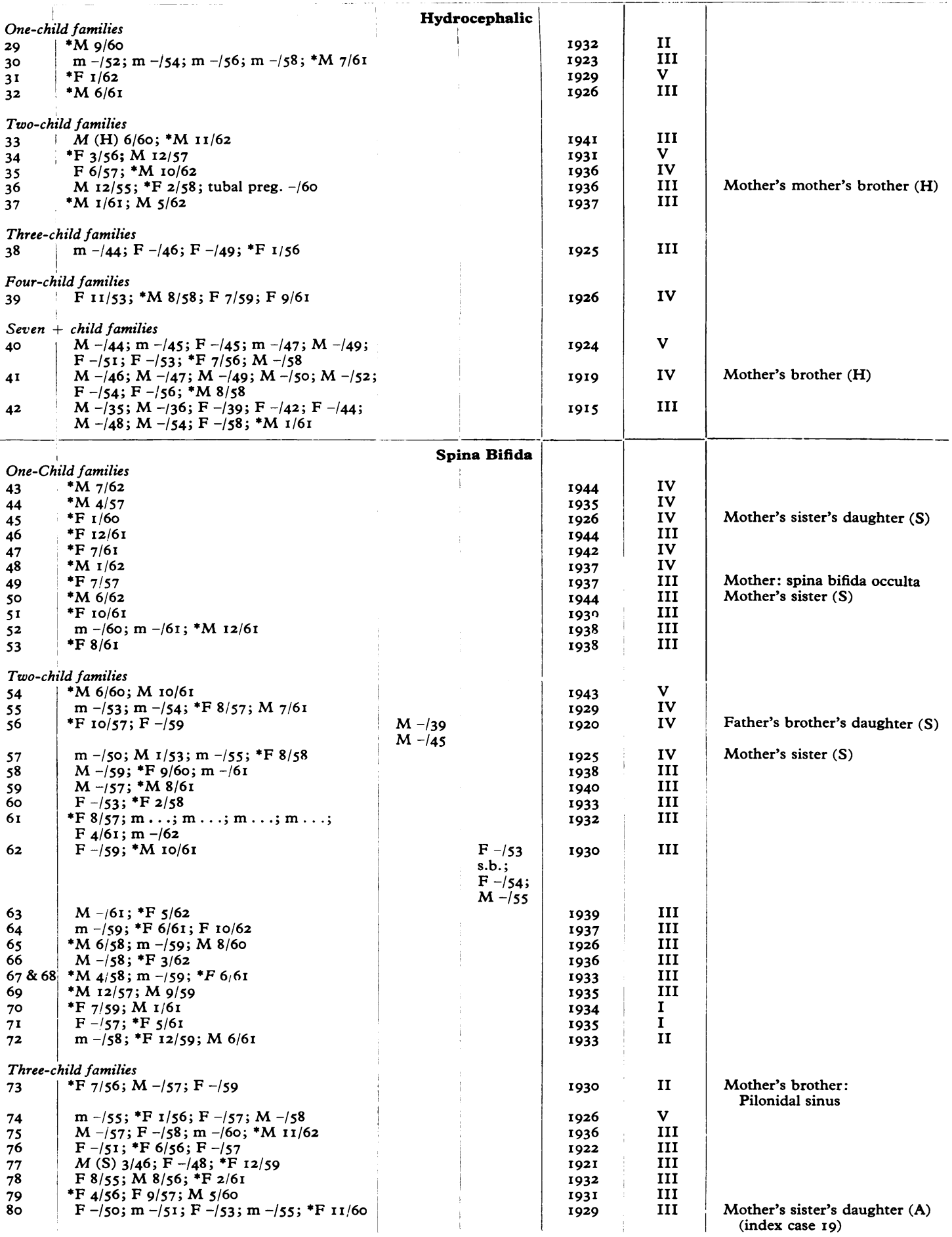




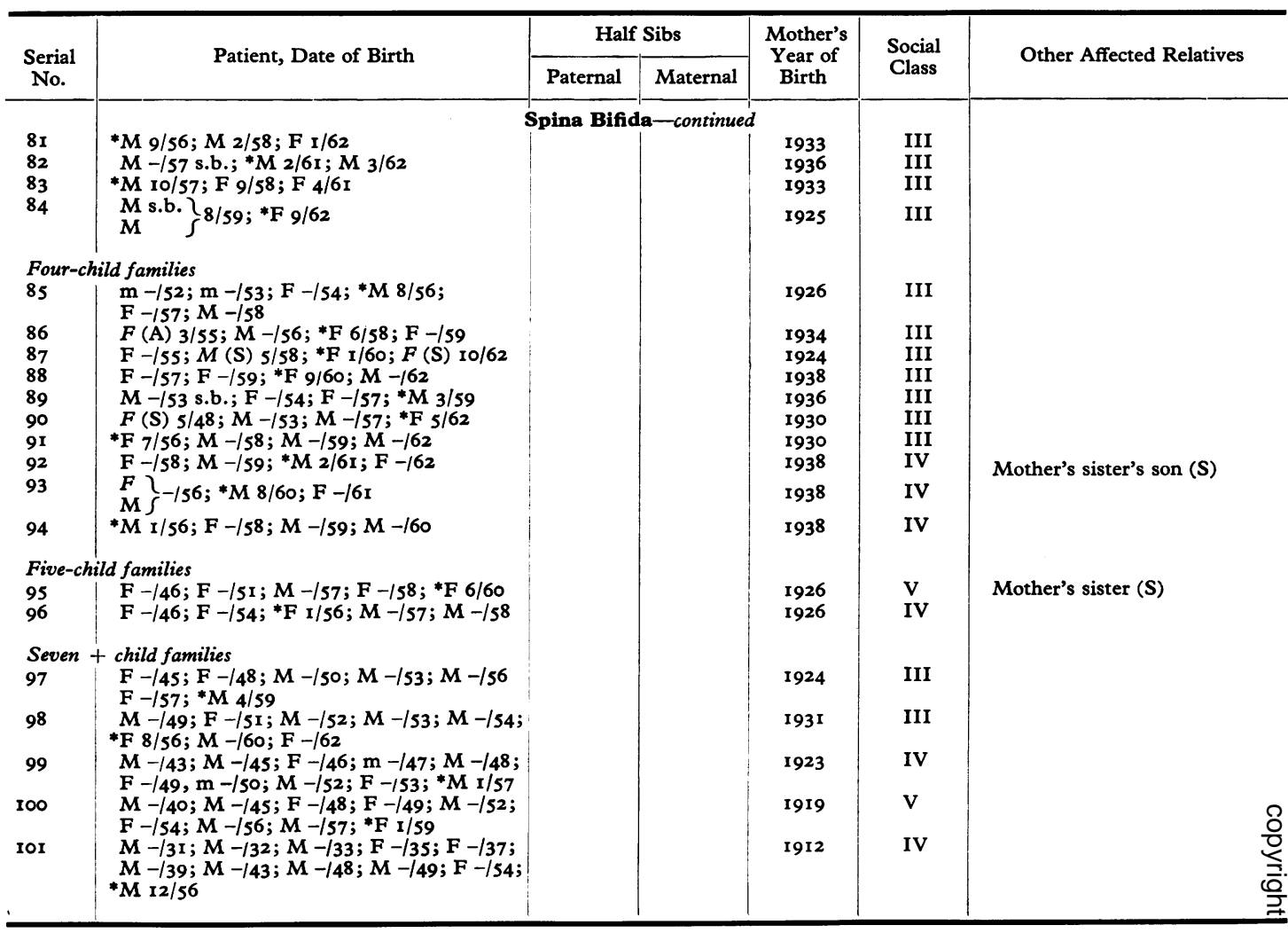

